\title{
Consumers' perception of the functional and symbolic performance failure of major electrical household appliances
}

\author{
Suné Donoghue, Helena $\mathrm{M}$ de Klerk and Lené Ehlers
}

\begin{abstract}
Opsomming
In hierdie studie word verbruikers se persepsies van die onklaarraak of defekte werkverrigting (produkmislukking, product failure) van bepaalde groot elektriese huishoudelike toerusting verken en beskryf. Die konfirmasie/diskonfirmasie-paradigma (Bearden \& Teel, 1983) dien as teoretiese agtergrond vir die studie. 'n Gerieflikheidsteekproef is gebruik om vraelyste, wat respondente self voltooi het, in te samel. Respondente moes uit 'n lys elektriese huishoudelike produkte 'n item kies wat die meeste ontevredenheid oor 'n tydperk van vier jaar veroorsaak het. Respondente moes die tipe produkmislukking aandui. Die resultate van die verkennende faktorontleding toon dat die respondente nie onderskei tussen die funksionele en simboliese werksverrigtingdimensies van toerusting wat faal nie. Verbruikers se ondevredenheid met hulle toerusting word dus, vanuit 'n teoretiese oopgunt, deur 'n kombi-nasie van beide funksionele en simboliese werksverrigtingdimensies bepaal.
\end{abstract}

Bemarkers, vervaardigers en kleinhandelaars moet in gedagte hou dat verbruikers nie tussen die funksionele en simboliese werksverrigtingdimensies onderskei wanneer hulle die werksverrigting van hulle toerusting evalueer nie. Dit het implikasie vir die suksesvolle hantering van verbruikers se klagtes. Personeel wat klagtes hanteer, moet deur die oë van hulle verbruikers na klagtes kyk (dws die mislukking van die werksverrigting van toerusting manifesteer in ' $n$ kombinasie van funksionele en simboliese dimensies) om groter begrip van verbruikers se ontevredenheid te verseker.

Beduidend meer respondente was baie ontevrede tot uiters ontevrede $(76 \%)$ met die werksverrigting van hulle groot elektriese huishoudelike toerusting teenoor die respondente wat effens tot matig ontevrede was $(24 \%)$.

Toekomstige navorsing oor die verskille tussen die onderskeie geslagsgroepe en verskillende kulturele groeperings se interpretasie van produkmislukkings (d.i. kognisie) en hulle gepaardgaande ontevredeheid (d.i. emosie), kan vervaardigers, kleinhandelaars en verbruikersorganisasies se begrip van verbruikers se klagtegedrag verbeter. Dit word gevolglik aanbeveel dat konsepsies van attribusieteorie geïntegreer (in lyn gebring) word met dié van die paradigma van die diskonfirmasie van verwagtinge om 'n teoretiese grondslag daar te stel vir die bestudering van verbruikers se klagtegedrag oor die mislukking van die werksverrigting van elektriese toerusting.

\author{
- Dr S Donoghue \\ Department of Consumer Science \\ University of Pretoria \\ - Prof HM de Klerk \\ Department of Consumer Science \\ University of Pretoria

\section{- Dr Lené Ehlers} \\ Department of Marketing Communication \\ Management, University of Pretoria
}

\section{INTRODUCTION}

Since the first democratic election in South Africa in 1994, the socio-economic and consumer environment has changed drastically due to the new socio-political dispensation. For example, many black people who previously lived in smaller towns and/or belonged to the lower socio-economic groups, have moved to urban areas and big cities where they now have the financial means and opportunity to purchase durable and expensive goods such as major electrical household appliances (Research Surveys, 2006; Nieftagodien \& Van der Berg, 2007).

Studies undertaken by the University of Cape Town's Unilever Institute of Strategic Marketing and Research Surveys describe the emerging black middle class as the "Black Diamonds", and estimate that the buying power of this group is $R 130 \mathrm{bn}$ (about $\$ 19 \mathrm{bn}$ ) per year - almost a quarter of South Africa's total consumer spending power of R 600bn. Like most newly rich people anywhere, the Black Diamond is a conspicuous consumer - cars, clothes, televisions sets, sound systems and household appliances top their list of desired and necessary objects. Black buyers are more brand conscious than their white counterparts and favour symbols of style and wealth (The Black Diamonds 2007 - on the move, 2007).

Donoghue and Erasmus (1999) confirmed that consumers buy major electrical household appliances not only for functional but also for symbolic purposes. These energy- and time-saving devices are important products without which many households (black and white South Africans) would not be able to function effectively. Moreover, these appliances are generally expensive, complex and expected to be durable. It is therefore of the utmost importance that consumers should be satisfied with the performance of their appliances. 
Before purchasing and using major electrical household appliances, consumers form expectations regarding the functional and symbolic performance dimensions of such appliances in a particular use situation. After or while using an appliance item, consumers evaluate its perceived performance in terms of their initial expectations for product performance. Whereas functional performance refers inter alia to durability, ease of use, ease of care and physical performance (how well the appliance does what it is supposed to do), symbolic performance refers to a "psychological" level of performance that is derived from the consumer's response to the physical product (Swan \& Combs, 1976; Erasmus \& Donoghue, 1998; Hawkins et al, 2001:641; Erasmus et al, 2005). When the appliance's performance does not meet the consumer's expectations (i.e. when a performance failure occurs or when the product performs poorly), negative disconfirmation occurs, leading to feelings of dissatisfaction. The traditional disconfirmation of expectations paradigm has been widely used in marketing literature to explain how consumers reach decisions concerning their satisfaction/dissatisfaction (Oliver \& DeSarbo, 1988; Chen-Yu et al, 1999; Steward in Ndubisi \& Ling, 2006).

The purpose of this research was to explore and describe consumers' perception of the performance failure of selected major electrical household appliances. The expectancy disconfirmation paradigm (Bearden \& Teel, 1983) served as theoretical background to this study. It should be noted here that this research formed part of a larger research project where the purpose was to explore and describe the role of specific consumer-related variables, product-specific variables, and causal attribution in dissatisfied consumers' complaint behaviour concerning the performance failure of selected major electrical household appliances.

\section{THE EXPECTANCY DISCONFIRMATION PARADIGM}

Most researchers describe the consumption evaluation process as a confirmation/disconfirmation paradigm whereby consumers compare their initial expectations for product performance with the perceived product performance and notice whether a difference (expectancy disconfirmation) exists (Blodgett \& Granbois, 1992). Refer to Figure 1. Whereas confirmation occurs when a product performs as expected, contributing to satisfaction or indifference (neutral feelings), positive or negative disconfirmation arises from discrepancies between prior expectations and actual performance, respectively leading to satisfaction and dissatisfaction (Swan \& Combs, 1976; Oliver \& DeSarbo, 1988; Chen-Yu et al, 1999; Steward in Ndubisi \& Ling, 2006).

According to Broadbridge and Marshall (1995), the duration of the consumption evaluation process is however dependent on the type of product. For example, consumers can decide immediately whether they are satisfied or dissatisfied with inexpensive and fast consumable products such as perishable food items.
In contrast, items that are used over longer periods beyond the immediate post-purchase stage, such as durable products, take longer to evaluate. Thus, the consumers' assessment of their satisfaction/ dissatisfaction with the actual performance of household appliances is an evolving process.

\section{Expectations about product performance}

Whether a particular item was purchased because of its presumed superior functional performance or for some other reason, consumers have some level of expected performance in mind, ranging from quite low to quite high, regarding the acquired appliance (Hawkins et al, 2001:639). Expectations in this context are therefore defined as beliefs or predictions about a product's expected performance. It can be termed "anticipated performance" or "what performance will (probably) be" (Laufer, 2002). Expectations are based upon prior experience with the product, word-of-mouth endorsements/criticisms and/or the marketing efforts of companies (Woodruff et al, 1983; Laufer, 2002). Thus, in addition to the experience factor, various personality and situational factors may affect the consumer's expectations of a product's performance (Day, 1977).

In the majority of studies using the confirmation/ disconfirmation paradigm, expectations are theorised as the standard or baseline for evaluating the quality of product performance (Chen-Yu et al, 1999). Woodruff et al (1983) suggest that consumers often have experiences beyond the product that they have actually purchased and used. For instance, experiences with various products and brands within the product class and comparable use situations. This may cause them to form different kinds of norms or standards, instead of expectations, that can be used to evaluate perceived product performance. However, these norms are constrained by the consumer's experiences with real products and brands and are therefore unlikely to be unachievable ideals.

Expanding the base of experiences to include other products means that consumers will probably go through a sequence of judgements leading to the choice of a standard for evaluating perceived product performance (Woodruff et al, 1983). Whereas the confirmation/disconfirmation paradigm limits comparison to experience with one product, the experience-based norm approach takes into consideration consumers' past experience. Therefore, expectations and experience-based norms are used frequently as the point of reference (standard of comparison) against which product performance is evaluated (Woodruff et al, 1983; Chen-Yu et al, 1999).

\section{Product performance}

Since performance expectations and actual performance are major factors in the evaluation process, and are related, it is essential to understand the dimensions of product performance. Expectations about product performance relate to both the functional (instrumental) and the symbolic (expressive) perform- 


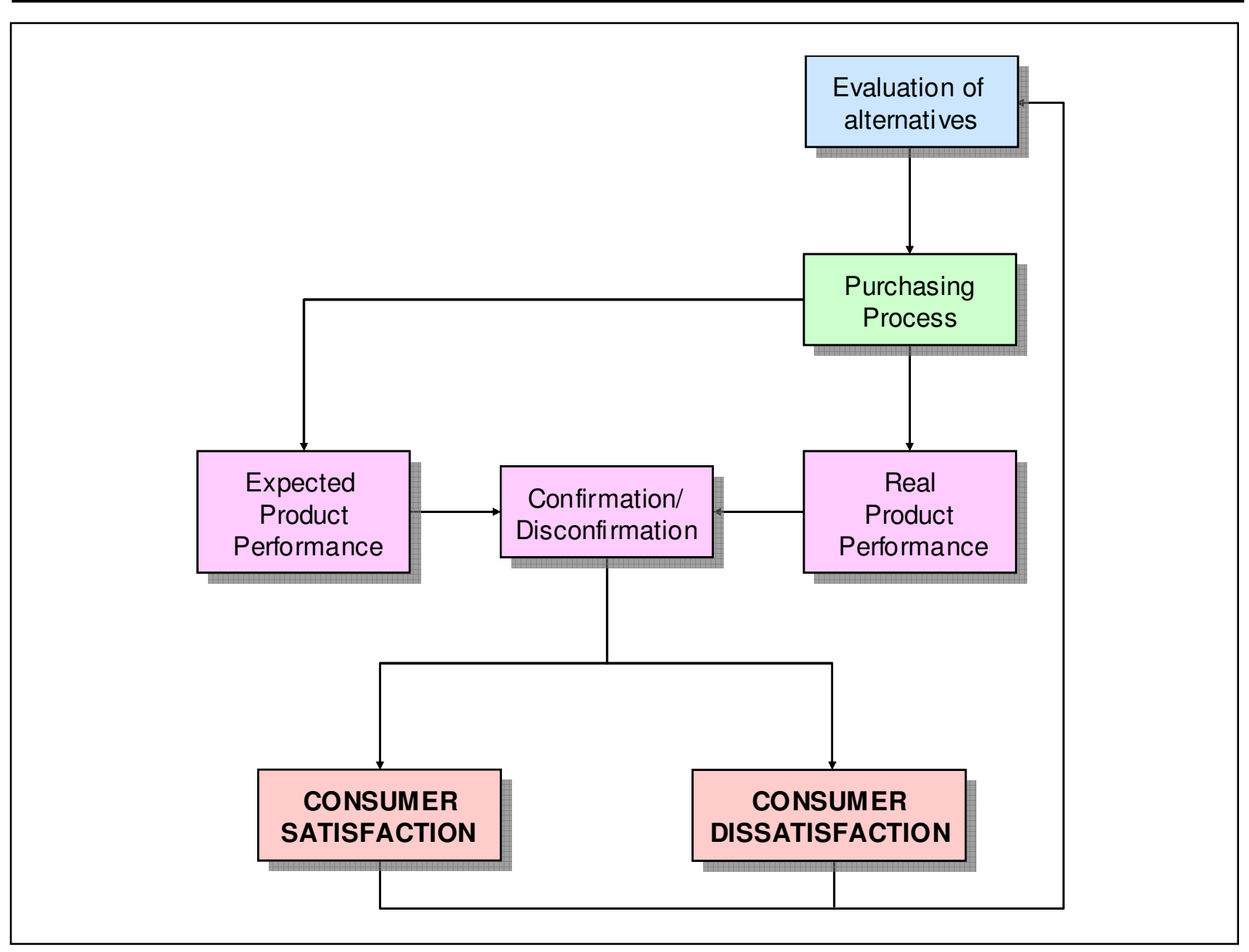

FIGURE 1 THE POST-PURCHASE EVALUATION PROCESS IN TERMS OF THE CONFIRMATION/ DISCONFIRMATION PARADIGM (LOUDON \& DELLA BITTA, 1993:579)

ance dimensions of the product (Swan \& Combs, 1976; Brown \& Rice, 1998:42; Hawkins et al, 2001:641).

Functional performance relates to the physical functioning of the products, i.e. the ability of the product to perform its functional, utilitarian or physical purposes. For example, proper product performance is vital to the evaluation of a dishwasher or any other major electrical household appliance. Depending on the type of product, functional performance refers inter alia to durability, ease of use, ease of care and physical performance (how well the product does what it is supposed to do). Conversely, a product's symbolic performance relates to a "psychological level of performance", such as what the product "does for", or symbolises to, the consumer - something that does not pertain to the direct properties of the physical product, but are derived from the consumer's response to the physical product (Swan \& Combs, 1976; AbrahamMurali \& Littrell, 1995; Brown \& Rice, 1998:38-39; Erasmus \& Donoghue, 1998; Hawkins et al, 2001:641; Erasmus et al, 2005).

Products have been known to provide symbolic meaning beyond their functional utility (Hyatt, 1992; Belk in Clarke et al, 2002). Therefore, products are consid- ered to be symbols by which people convey something about themselves, to themselves and to others (Donoghue \& Erasmus, 1999). The essence of a product, then, becomes not the physical product itself, but the relation between the product, its owner and the rest of society (Hyatt, 1992). This is especially applicable to conspicuous products that might be intended for aesthetic satisfaction and image-enhancement performance. "If a product consumption is conspicuous in public and is socially visible, consumers are likely to use the visibility of the product to communicate symbolically something about themselves to the 'significant others' in the consumption situation" (Lee, 1990:387; Vigneron \& Johnson, 1999). Therefore, major electrical household appliances may fulfil the consumer's emotional needs such as impressing others and winning admiration from those invited into their homes (Donoghue \& Erasmus, 1999).

The question arises whether the functional or the symbolic product performance dimension is more significant to consumers as they evaluate product performance. The answer to this question would undoubtedly differ in terms of the type of product and specific consumer group. Whereas evidence from the literature hints that for some products, determinant attributes may involve primarily functional performance, both 
symbolic and functional performance dimensions may be features for other products (Swan \& Combs, 1976; Hawkins et al, 2001:641)

Swan and Combs (1976) examined the relationship between expectations, performance and satisfaction/ dissatisfaction. In particular, they investigated the effect of the functional and the symbolic dimensions of product performance - in this case, the product was clothing - on consumers' experience of satisfaction or dissatisfaction. Findings concerning functional and symbolic performance suggested that satisfaction and dissatisfaction are linked to qualitatively different kinds of performance results. Satisfactory clothing items tended to be associated with symbolic performance results and dissatisfactory items tended to be associated with functional performance results. It was concluded that satisfactory clothing items may involve both symbolic and functional outcomes, while dissatisfactory items were likely to involve functional rather than symbolic outcomes.

Swan and Combs (1976) developed and applied their concept of consumer satisfaction as related to the functional and symbolic dimensions of product performance to clothing products only - implying that the applicability of the concept to other products, such as major electrical household appliances, needs to be empirically tested.

\section{Satisfaction/dissatisfaction}

In the confirmation/disconfirmation paradigm, postconsumption consumer satisfaction/dissatisfaction (CS/CD) can theoretically be described as the consumer's response to the evaluation of the perceived discrepancy between prior expectations (or some other norm of performance) and the actual performance of the product as perceived after its consumption (Day, 1984). Differently stated, consumer satisfaction/ dissatisfaction (CS/D) is conceptualised as a positive/ negative feeling (emotion), in response to, or following, a specific consumption experience (Woodruff et al, 1983; Day, 1984; Blodgett \& Granbois, 1992; Erasmus \& Donoghue, 1998; Brijball, 2000).

\section{Satisfaction/dissatisfaction outcomes}

Consumer satisfaction, as a consequence of the purchase/consumption experience, would appear to be an important variable in linking product selection with other post-purchase outcomes including favourable post-purchase attitudes, positive word-of-mouth, higher purchase intentions and consumer loyalty. In contrast, the study of post-purchase dissatisfaction is equally important because of its close linkages with negative outcomes such as less favourable purchase attitudes, lower or non-existent purchase intentions, negative word-of-mouth, complaining, and changes in shopping behaviour such as brand or product switching and retailer boycotts (Bearden \& Teel, 1983; Loudon \& Della Bitta, 1993:581; Chen-Yu et al, 1999; Brijball, 2000)

\section{UNIT OF ANALYSIS}

The units of analysis for this study were consumers who had purchased major electrical appliances (i.e. kitchen and laundry appliances) during a prior fouryear recall period and have experienced dissatisfaction concerning the performance of an appliance item. Respondents had to use their own appliances to have gained such experience, since their evaluation of the actual performance of household appliances would take longer compared to the evaluation of perishable products. Additionally, consumers had to be older than 25 years of age, had to belong to the Living Standards Measure (LSM) groups 5 to 10, and had to reside in the greater Pretoria area. It was assumed that by the age of 25 years, the average person would be earning enough income to purchase and subsequently operate his/her appliances.

For LSM levels 5 to 10 , characteristics include (in ascending order): access to electricity, ownership of durables such as major electrical household appliances, educational levels varying from schooling up to Matric/Grade 12 to higher education, and average monthly household incomes ranging from R2 000 to R10 000 or higher (i.e. middle-class to top income brackets). Therefore, members of LSM groups 5 to 10 have access to electricity and have the capacity to own major electrical appliances (SAARF Universal LSM Descriptors, August 2004). Since members from the different LSM groups might stay in the same suburbs, regardless of the living standard, it was decided that respondents could be drawn from any of the suburbs of the Pretoria area.

\section{METHODOLOGY}

\section{Sample}

A convenience sampling technique was employed, although sample members were selected on the basis of the pre-specified criteria mentioned in the abovementioned paragraphs. A self-administered questionnaire was administered after being pilot-tested on eight people having characteristics similar to those of the target group of respondents.

\section{Data collection}

Fieldworkers (including students and employees from a local retailer) were trained to aid the researcher in the distribution and collection of the data. The fieldworkers were remunerated for their efforts. Fieldworkers delivered questionnaires by hand to individual respondents after ascertaining whether the respondents complied with the criteria set for inclusion in the study. The respondents were pre-screened, and only those who had experienced dissatisfaction with a major electrical household appliance item within the prior four years, were included in this study. In this study the absolute minimum number of responses required for the factor analysis was determined at 100, according to the rule of 100 (the number of respondents should be larger than 5 times the number of variables, 
or 100) (Hatcher in Statistic Solutions, Inc, 19962007).

\section{The development of the questionnaire}

The questionnaire was compiled after an in-depth review of the literature concerning consumer satisfaction/dissatisfaction theory in terms of the confirmation/ disconfirmation paradigm, consumers' expectations about product performance and the dimensions of product performance. Whereas various empirical studies and academic literature exist concerning consumers' perceptions of the functional and symbolic performance dimensions of products such as clothing, information about the performance failure dimensions of major electrical household appliances is very limited.

Therefore, additional sources of information were investigated to aid the researcher in designing questionnaire items for the dimensions of product performance. Written information, including newspaper complaint letters and online letters to consumer complaint websites, was explored to become acquainted with the type of product problems that consumers experienced concerning the performance failure of major electrical household appliances. Complaint letters, published between 2001 and 2006, concerning consumer's dissatisfaction with the performance of their major electrical household appliances, were considered. These letters are respectively available on a local (Afrikaans) newspaper's website (Beeld) and Internet websites such as consumeraffairs.com (http:// www.consumeraffairs.com). Owners' manuals (instruction leaflets) of top appliance manufacturers were studied to become aware of the special features that these manufacturers lay claim to, and so identify possible examples of performance failures that consumers might encounter. These claims were adapted to suggest product performance failures.

Exploratory research thus enabled the researcher to gain a better understanding of the functional and symbolic performance dimensions of major electrical household appliances and to explicate these concepts. For the purpose of this research, functional performance failures were classified into the following categories: unusual product performance in terms of the intended end-use, failure/breakdown of appliance or some component(s) thereof, inconvenience in operating the appliances, inconvenience/difficulty in the maintenance and care of the appliance, insufficient durability and safety or health risks associated with performance of the appliance. The symbolic performance failures of appliances refer to the sensory, emotional and cognitive displeasure or dissatisfaction associated with major electrical household appliances. Refer to Table 1 for the distinctive performance dimensions, accompanying indicators and quotations from the complaint letters and owners' manuals concerning these performance failures. (It should be noted that Table 1 shows 9 categories ( 6 for functional performance and 3 for symbolic performance) that were inferred from the exploratory research).

\section{Procedure}

The questionnaire required respondents to provide demographic information (i.e. gender, age, level of education, monthly household income, residential area, cultural group) and information concerning their dissatisfaction with the functional/symbolic performance failure of major electrical household appliances. Respondents had to select an appliance item from a list of appliances provided, that had caused them the most dissatisfaction within the last four years. Respondents had to describe the type of product failure (i.e. what went wrong) in an open-ended question. Additionally, a Likert-type scale, with ten items (statements) (inferred from the exploratory research) concerning the functional and symbolic performance of major electrical household appliances, was used to determine the type of performance failure (functional or symbolic) that caused the dissatisfaction.(It should be noted that the Likert-type scale consisted of 5 items for functional performance and 5 items for symbolic performance. More items were included for symbolic performance to ensure that the items measure the relevant construct and not something else). Respondents were asked to indicate the degree to which they agreed/disagreed with these (ten) items by using a five-point Likert-type scale $(1=$ definitely agree, $2=$ agree, $3=$ uncertain, $4=$ disagree and $5=$ definitely disagree). Respondents also had to indicate their level of dissatisfaction experienced when their appliance's performance was faulty or poorly on a 4-point dissatisfaction response scale $(1=$ slightly dissatisfied, $2=$ moderately dissatisfied, $3=$ very dissatisfied, $4=$ extremely dissatisfied).

\section{Data analysis}

Data analysis comprised of descriptive and inferential statistics. Frequency tables categorised responses into functional and symbolic performance dimensions (Table 2) while exploratory factor analysis and the ztest were also employed for further analysis (Tables 3 and 4).

Common factor analysis focuses on the common variance shared among the original variables and seeks to identify underlying dimensions (known as "common factors"). To the extent that subsets among original variables reflect a common core (i.e. are measuring the same underlying construct), the derived dimensions should be meaningful and interpretable. The original variables can then be described in terms of the common underlying dimensions. Common factor analysis is particularly useful in the context of measurement development, as it enables an assessment of the dimensionality of a multi-item scale (Diamantopoulos \& Schlegelmilch, 2000:216).

In this study, oblique rotation (i.e. direct quartimin rotation) was used. Oblique rotation are use to weed out those variables that fail to show high loading on a specific factor. Whereas high factor loadings imply that items load highly on a factor(s), providing the most meaning to the factor solution, low factor loadings imply that items do not load highly on a factor(s). A 

LETTERS AND OWNERS' MANUALS

\begin{tabular}{|c|c|c|}
\hline $\begin{array}{l}\text { Performance } \\
\text { dimensions }\end{array}$ & Indicators & $\begin{array}{l}\text { Quotations from complaint letters and owners' } \\
\text { manuals }\end{array}$ \\
\hline \multirow[t]{6}{*}{$\begin{array}{l}\text { Functional per- } \\
\text { formance }\end{array}$} & $\begin{array}{l}\text { Unusual performance/ } \\
\text { functioning in terms of intended end- } \\
\text { use }\end{array}$ & $\begin{array}{l}\text { "... after one week all the numbers that indicates the } \\
\text { heat of the plates came off, even the red light cover } \\
\text { came loose ...!" }\end{array}$ \\
\hline & $\begin{array}{l}\text { Failure/breakdown of appliance or } \\
\text { some component(s) thereof }\end{array}$ & "In August last year, the machine started jamming ..." \\
\hline & $\begin{array}{l}\text { Inconvenience in operating the ap- } \\
\text { pliances (physical discomfort, waste } \\
\text { of time and energy etc.) }\end{array}$ & $\begin{array}{l}\text { "The appliance was not simple and easy to use - you } \\
\text { are 'guaranteed simple operation and intuitive use'." }\end{array}$ \\
\hline & $\begin{array}{l}\text { Inconvenience/difficulty in the main- } \\
\text { tenance and care of the appliance }\end{array}$ & $\begin{array}{l}\text { "In my opinion, I should not have to wash the dish- } \\
\text { washer after a load of dishes." }\end{array}$ \\
\hline & Insufficient durability & $\begin{array}{l}\text { "The refrigerator was only in use for one year when it } \\
\text { started making lumps of ice. I cannot understand why } \\
\text { a refrigerator is manufactured to last only two ye- } \\
\text { ars..." }\end{array}$ \\
\hline & $\begin{array}{l}\text { Safety or health risks associated } \\
\text { with the appliance }\end{array}$ & $\begin{array}{l}\text { "The microwave oven started to shoot sparks and } \\
\text { make a 'hot electronics' smell. The result will be our } \\
\text { having to spend more money in order to replace or fix } \\
\text { a defective product that is dangerous in its mal- } \\
\text { function." }\end{array}$ \\
\hline \multirow[t]{3}{*}{$\begin{array}{l}\text { Symbolic per- } \\
\text { formance }\end{array}$} & $\begin{array}{l}\text { Lack of sensory pleasure or sensory } \\
\text { dissatisfaction }\end{array}$ & $\begin{array}{l}\text { "I had a microwave which we used for almost } 15 \\
\text { years but needed to buy a new one to match our } \\
\text { new kitchen appliances ..." }\end{array}$ \\
\hline & $\begin{array}{l}\text { Lack of an emotionally pleasurable } \\
\text { experience/emotional dissatisfaction }\end{array}$ & $\begin{array}{l}\text { "...I can't stand much more of this. Whatever hap- } \\
\text { pened to the saying - They're built to last." }\end{array}$ \\
\hline & $\begin{array}{l}\text { Lack of cognitive pleasure (cognitive } \\
\text { dissatisfaction) }\end{array}$ & $\begin{array}{l}\text { "Other people (friends/family) were not particularly } \\
\text { impressed with the appliance's image ..." }\end{array}$ \\
\hline
\end{tabular}

Scree test was used to determine the number of factors to be extracted. The decision rule for including or excluding items from factors was 0,30 . Cronbach's alpha is the most common estimate of the internal consistency or reliability of items in a scale. A widely accepted assumption in the social science is that alpha should be 0,70 or higher for a set of items to be considered a scale (Statistics Solutions: Factor Analysis).

\section{RESULTS AND DISCUSSION}

\section{Demographic information}

A total number of 216 questionnaires were collected between February and April 2006. A total of $70 \%$ of the respondents were female, while $30 \%$ were male. The majority $(72 \%)$ of the respondents were $25-45$ years of age, while $28 \%$ were $46-83$ years old. Whereas a total of $21 \%$ of the respondents' highest level of education was Grade 12/Standard 10/NTCIII or less, $36 \%$ of the respondents had Grade 12 and an additional certificate(s)/diploma(s). A total of $43 \%$ of the sample held either a Bachelors degree or a postgraduate qualification. A total of $26 \%$ and $27 \%$ of the respondents fell in the monthly household income categories of R $2000-R 5000$ and R $5001-R 10$ 000 respectively. A total of $47 \%$ of the respondents belonged to the monthly household income category of R 10001 or more. About two thirds of the respondents $(69 \%)$ were Caucasian, while nearly a third of the respondents $(31 \%)$ were black.

\section{Functional and/or symbolic performance failure}

The response for the open question (what happened/ went wrong?) was analysed and the different performance dimensions and indicators mentioned in Table 1 were considered. It should be noted that the data is expressed in terms of the number of responses obtained (whereas 216 respondents answered the question, 317 responses were obtained concerning the different performance dimensions). See Table 2. (It should be noted that Table 2 shows only seven categories ( 5 for functional performance and 2 for symbolic performance) since these categories emerged from the respondents themselves).

Table 2 shows that more responses (311) were obtained for the functional performance dimension as compared to the symbolic performance dimension (6), indicating more problems concerning the functional performance of major electrical household appliances as compared to their symbolic performance. Unusual product performance/functioning in terms of the intended end-use $(52,68 \%$ of the responses) and failure/breakdown of the appliance or some component (s) thereof $(27,44 \%$ of the responses) were the two major functional product performance categories experienced. Relatively few responses indicated incon- 
TABLE 2: $\quad$ DESCRIPTIONS OF WHAT HAPPENED/WENT WRONG IN TERMS OF INDICATORS FOR FUNCTIONAL AND SYMBOLIC PRODUCT PERFORMANCE DIMENSIONS ( $N=216 ; 317$ responses)

\begin{tabular}{|c|c|c|c|}
\hline $\begin{array}{l}\text { Performance } \\
\text { dimensions }\end{array}$ & Indicators & $\begin{array}{l}\text { Number of re- } \\
\text { sponses }\end{array}$ & Percentage \\
\hline \multirow[t]{5}{*}{$\begin{array}{l}\text { Functional } \\
\text { performance }\end{array}$} & $\begin{array}{l}\text { Unusual performance/ } \\
\text { functioning in terms of intended end-use }\end{array}$ & 167 & 52,68 \\
\hline & $\begin{array}{l}\text { Failure/breakdown of appliance or some } \\
\text { component(s) thereof }\end{array}$ & 87 & 27,44 \\
\hline & $\begin{array}{l}\text { Inconvenience in operating the appliances } \\
\text { (physical discomfort, waste of time and } \\
\text { energy etc.) }\end{array}$ & 20 & 6,31 \\
\hline & $\begin{array}{l}\text { Inconvenience/difficulty in the maintenance } \\
\text { and care of the appliance }\end{array}$ & 6 & 1,89 \\
\hline & Insufficient durability & 31 & 9,87 \\
\hline \multirow[t]{3}{*}{ Symbolic performance } & $\begin{array}{l}\text { Lack of sensory pleasure, or sensory dis- } \\
\text { satisfaction }\end{array}$ & 1 & 0,32 \\
\hline & $\begin{array}{l}\text { Lack of an emotionally pleasurable experi- } \\
\text { ence/emotional dissatisfaction }\end{array}$ & 5 & 1,58 \\
\hline & Total responses & 317 & 100,00 \\
\hline
\end{tabular}

venience experienced in operating $(6,31 \%)$ and maintaining/caring $(1,89 \%)$ for their dissatisfactory appliances. Only $9.87 \%$ responses were obtained for insufficient durability. Hardly any responses $(1,90 \%)$ were obtained for product problems relating to the symbolic performance of their appliances. This is in line with what one would expect, namely that consumers' dissatisfaction with household appliances would be determined mainly by the functional performance failures and to a lesser degree by symbolic failures, since the major function of these products are "to perform their job well to save time and energy". It might also be that respondents found it easier to express themselves in terms of the functional performance of appliances since symbolic performance is more abstract and therefore difficult to verbalise.

The responses to the 10 items for the Likert-type scale were subjected to an exploratory factor analysis to determine whether respondents perceived the functional and symbolic performance failure (dimensions) of major electrical household appliances differently. It was expected that the variables of "the appliance broke down", "the appliance did not operate properly", "the appliance was a dud (unusual example of a poor product) from the start", "the appliance did not provide user convenience" and "the appliance required more maintenance and care compared to similar appliances in a faultless condition" would load highly in terms of functional product performance, and that the variables of "the appliance no longer reflected the image/identity I associated with my personal style", "the appliance no longer made me feel good about myself", "I did not enjoy using the appliance any longer", "the appliance no longer impressed me" and "the appliance no longer impressed other people" would load highly in terms of symbolic product performance factor. However, contrary to expectations, a Scree test suggested that only one factor could be extracted (labelled the combined functional and symbolic performance factor). (eigenvaluen $=3,532$ ). (An eigenvalue above 1 indicates only 1 common factor). To enhance the reliability of the scale, two items with low loadings (i.e. "the appliance broke down" and "the appliance did not operate properly") were eliminated (i.e. not included) when calculating the Cronbach's alpha. The resulting factor loadings, for the combined functional and sym-

TABLE 3:

ROTATED FACTOR LOADINGS FOR THE COMBINED FUNCTIONAL AND SYMBOLIC PERFORMANCE FACTOR

\begin{tabular}{|l|c|}
\hline Items & Factor loadings \\
\hline The appliance was a dud (unusual example of a poor product) from the start & 0,437 \\
\hline The appliance did not provide user convenience & 0,384 \\
\hline The appliance required more maintenance and care compared to similar appliances in \\
a faultless condition
\end{tabular}

Percentage variance explained 36,82

Cronbach's alpha 0,8131 
TABLE 4: LEVEL OF DISSATISFACTION EXPERIENCED WHEN THE APPLIANCES' PERFORMANCE WAS FAULTY OR POOR ( $\mathrm{N}=\mathbf{2 1 6}$ )

\begin{tabular}{|c|c|c|c|c|}
\hline $\begin{array}{l}\text { Level of dissatisfaction } \\
\text { experienced }\end{array}$ & Frequency & Percentage & $\begin{array}{c}\text { Percentage } \\
n=215\end{array}$ & $\begin{array}{c}\text { p-value } \\
\text { z-test for equal } \\
\text { proportions }\end{array}$ \\
\hline Slightly dissatisfied & 13 & 6,05 & \multirow[b]{2}{*}{23,72} & \multirow[t]{6}{*}{$0,0001^{*}$} \\
\hline Moderately dissatisfied & 38 & 17,67 & & \\
\hline Very dissatisfied & 112 & 52,09 & \multirow[b]{2}{*}{76,28} & \\
\hline Extremely dissatisfied & 52 & 24,19 & & \\
\hline Missing & 1 & & & \\
\hline Total & 216 & 100.00 & 100,00 & \\
\hline
\end{tabular}

bol performance factor, after the two items with low loadings were deleted, are indicated in Table 3.

The results portrayed in Table 3 suggest that the 8 items that loaded on the combined functional and symbolic performance factor were reliable $(\alpha=0,81)$. Although the factor loadings for the items concerning symbolic performance are higher than the corresponding loadings for the items concerning functional performance, it should be noted that all the items loaded on only one factor.

When looking deeper than the surface (results of the open questions), the results of the factor analysis show that respondents did not differentiate between the functional and the symbolic performance failures of appliances. Therefore, both the functional and symbolic failures were considered important in consumers' evaluation of the performance of their dissatisfactory appliances.

\section{Dissatisfaction}

When the categories of slightly dissatisfied with moderately dissatisfied $(6,05 \%+17,67 \%)$ and very dissatisfied with extremely dissatisfied $(52,09 \%+24,19 \%)$ were combined, it was evident that $23,72 \%$ and $76,28 \%$ respondents fell within these two larger categories respectively. Refer to Table 4.

The results of the z-test for equal proportions indicate that a significant difference exists between these proportions $(p$-value $=0,0001)$. Significantly more respondents were very dissatisfied to extremely dissatisfied $(76,28 \%)$ with the performance of their major electrical household appliances, compared to the respondents who were slightly to moderately dissatisfied $(23,72 \%)$.

\section{CONTRIBUTION, IMPLICATIONS AND RECOMMENDATIONS}

Even though the results of the study are limited to the specific sample, which means that the findings cannot be generalised to the larger South African population (due to the convenience sampling technique), marketing analysts, retailers and manufacturers could benefit from the implications of this study.

As far as major electrical household appliances are concerned, the constructs of functional and symbolic performance failures cannot be regarded as individual constructs, but should be regarded as a combined construct when explaining appliance failures. Therefore, from a theoretical point of view, consumers' dissatisfaction with their appliances is determined by a combination of both functional and symbolic performance results. Other product industries (selling status symbols such as cars, clothing and furniture) could certainly benefit from similar research concerning their customers' cognitions and emotions when product performance does not meet their expectations (i.e. when a performance failure occurs or when the product performs poorly).

Since consumers' expectations are partly based on the marketing efforts of companies, companies' promotional efforts concerning the performance of appliances should be realistic, in order to avoid creating false expectations concerning the anticipated benefits to be derived directly from the products themselves (i.e. functional utility), and/or other benefits resulting from the purchase and use of appliances (i.e. what the product does for, or symbolises to, the consumer). More information about the operation, maintenance and care of appliances should be provided to consumers via in-store marketing and advertising materials. This will give retailers and manufacturers the opportunity to resolve consumers' product dissatisfactions.

Marketing analysts, retailers and manufacturers should keep in mind the fact that consumers do not differentiate between the functional and the symbolic performance dimensions of product performance when evaluating the actual performance of appliances - consumers actually use these qualitatively different kinds of performance dimensions in combination with one another. This has implications for the effective handling of complaints concerning dissatisfactory major electrical household appliances. Complaint handling personnel should see complaints through the eyes of customers (i.e. as a combination of functional and symbolic performance failures) to improve their understanding of the customers' dissatisfaction.

\section{Recommendations for following research}

It would be worthwhile to investigate the association between demographic variables (i.e. gender, age, level of education, household monthly income and culture) and the functional/symbolic performance failure of major electrical household appliances to explain the role of consumers' demographics in their interpretation (evaluation) of functional and symbolic 
product performance failures. Research on the disparities between gender groups and the different cultural groupings concerning consumers' interpretation of product failures (i.e. cognition) and their dissatisfaction (i.e. emotion), can improve retailers', manufacturers' and consumer organisations' comprehension of consumers' complaint behaviour. Hence, it is recommended that conceptions of attribution theory be integrated (aligned) with the expectancy disconfirmation paradigm to develop a theoretical basis for studying consumers' complaint behaviour concerning appliance performance failures.

\section{REFERENCES}

ABRAHAM-MURALI, L \& LITTRELL, MA. 1995. Consumers' conceptualisation of apparel attributes. Clothing and Textiles Research Journal 13(2):65-74.

BEARDEN, WO \& TEEL, JE. 1983. Selected determinants of consumer satisfaction and complaint reports. Journal of Marketing Research 20:21-28.

BLODGETT, J \& GRANBOIS, D. 1992. Toward an integrated conceptual model of consumer complaining behavior. Journal of Consumer Satisfaction, Dissatisfaction and Complaining Behavior 5:93-103.

BRIJBALL, S. 2000. Post-purchase advertisement readership behaviour and repeat purchase intentions of motor vehicle consumers. Journal of Industrial Psychology 26(2):44-49.

BROADBRIDGE, A \& MARSHALL, J. 1995. Consumer complaint behavior: the case of electrical goods. International Journal of Retail \& Distribution Management 23(9):8-18.

BROWN, P \& RICE, J. 1998. Ready-to-wear apparel analysis. $2^{\text {nd }}$ ed. Upper Saddle River, NJ. Merrill Prentice-Hall.

CHEN-YU, HJ, WILLIAMS, G \& KINCADE, DH. 1999. Determinants of consumer satisfaction/dissatisfaction with the performance of apparel products. Family and Consumer Sciences Research Journal 28(2):167-192. CLARKE, I, MICKEN, KS \& HART, HS. 2002. Symbols for sale... at least for now: symbolic consumption in transition economies. Advances in Consumer Research 29(1):25-30.

DAY, RL. 1977. Extending the concept of consumer satisfaction. Advances in Consumer Research 4 (1):149-154.

DAY, RL. 1984. Modelling choices among alternative responses to dissatisfaction. Advances in Consumer Research 11(1):496-499.

DONOGHUE, S \& ERASMUS, AC. 1999. Sosiale motiewe en stereotipering in verbruikers se keuse van groot elektriese huishoudelike toerusting. Tydskrif vir Gesinsekologie en Verbruikerswetenskappe 27(1):1423.

ERASMUS, AC \& DONOGHUE, S. 1998. Consumer satisfaction - an unattainable ideal? Journal for Family Ecology and Consumer Sciences 26(1):35-42.

ERASMUS, AC, MAKGOPA, MM \& KACHALE, MG. 2005. The paradox of progress: inexperienced consumers' choice of major household appliances. Jour- nal for Family Ecology and Consumer Sciences 33:89101.

HAWKINS, DI, BEST, RJ \& CONEY, KA. 2001. Consumer behavior. Building marketing strategy. $8^{\text {th }}$ ed. Boston. Irwin/McGraw-Hill.

HYATT, EM. 1992. Consumer stereotyping: The cognitive bases of the social symbolism of products. Advances in Consumer Research 19(1):299-303.

LAUFER, D. 2002. Are antecedents of consumer dissatisfaction and consumer attributions for product failures universal? Advances in Consumer Research 29 (1):312-317.

LEE, D.H. 1990. Symbolic interactionism: some implications for consumer self-concept and product symbolism research. Advances in Consumer Research, vol. 17, no. 1, p. 386-393.

LOUDON, DL \& DELLA BITTA, AJ. 1993. Consumer behavior: concepts and applications. $4^{\text {th }}$ ed. New York. McGraw-Hill.

NDUBISI, NO \& LING, TY. 2006. Complaint behaviour of Malaysian consumers. Management Research News 29(1/2):65-76.

NIEFTAGODIEN, S \& VAN DER BERG, S. 2007. Consumptions patterns and the black middle class: The role of assets. Stellenbosch Economic Working Paper 2/2007. Department of Economics \& Bureau for Economic Research, University of Stellenbosch.

OLIVER, RL \& DeSARBO, WS. 1988. Response determinants in satisfaction judgments. Journal of Consumer Research 14:495-507.

RESEARCH SURVEYS. 2006. The new black middle class: Its economic power. Press release. 10 March 2006.

ROUSSEAU, D. 2003. Cultural influences on buyer behaviour. In Du Plessis PJ \& Rousseau GG. Buyer Behaviour. A multi-cultural approach to consumer decision-making in South Africa. Cape Town. Oxford University Press.

SAARF UNIVERSAL LSM DESCRIPTORS, August 2004. Available on line. URL: www.saarf.co.za.

SINGH, J. 1988. Consumer complaint intentions and behavior: definitional and taxonomical issues. Journal of Marketing 52(1): 93-107.

STATISTICS SOLUTIONS, Inc. 1996-2007. Factor analysis. Available on line. URL: www.statisticsolutions.com/Factor-Analysis.htm.

SWAN, JE \& COMBS, LJ. 1976. Product performance and consumer satisfaction. Journal of Marketing 40:25 $-33$.

THE BLACK DIAMONDS 2007 - ON THE MOVE. 2007. UCT Unilever Institute and TNS Research Surveys.

VIGNERON, F \& JOHNSON, LW. 1999. A review and a conceptual framework of prestige-seeking consumer behaviour. Academy of Marketing Science Review 1999(1):1-15.

WEINER, B. 2000. Attributional thought about consumer behavior. Journal of Consumer Research. 27 (3):382-387.

WOODRUFF, RB, CADOTTE, ER \& JENKINS, RL. 1983. Modelling consumer satisfaction processes using experience based norms. Journal of Marketing Research 20(3):296-304. 